www.czasopisma.marszalek.com.pl/pl/10-15804/npw

\author{
AgNIESZKA TOMCZYK \\ Uniwersytet Warszawski \\ ORCID: https://orcid.org/0000-0001-7063-5130
}

\title{
Zjawisko borderyzacji w polityce gruzińskich i osetyjskich elit władzy
}

\section{Borderization in the politics of Georgian and South Ossetian power elites}

\section{Abstract}

The dissolution of the Soviet Union led to both the restoration of independent states and the emergence of entities with the status of unrecognized states. In the aftermath of the five-day Georgia-Russia conflict of August 2008, the borderization incidents have intensified. The process involves the installation of barbed fences along the Administrative Boundary Line (ABL) between Georgia and South Ossetia, and shifting border marks deep into the Georgia-controlled territory to transform the official ceasefire line into an international border by the Russian FSB border guards. The paper aims to examine how 'borderization' activities have affected the politics of Georgian and South Ossetian ruling elites. By becoming a part of the political and social debate, border incidents have allowed victimization the Georgian nation to be presented to the world. However, especially in 2012-2013, the two main political parties in Georgia differed in their perceptions of borderization. From South Ossetian perspective, in turn, the process has served as a manifestation of strengthening national identity, independence from Georgia, and above all, the belief in Ossetian statehood guaranteed by Russia's military presence and the growing importance of the military elite. The methodology of the work is based on the case study approach, as well as critical analysis of literature, documents, web content and a review of archival materials. The paper also includes data obtained during the 
2018 and 2019 field research in Abkhazia and in the IDPs camp in Shavshvebi, near the Georgian-Ossetian border.

Keywords: South Ossetia, unrecognized state, borderization, political elites, Georgia, Russia

\section{"Бордеризация" в политике властных элит Грузии и Южной Осетии}

\section{Аннотация}

Распад Советского Союза принес бывшим республикам независимость, но в тоже время послужил причиной возникновения спорных территорий, претендующих на статус независимых государств. В результате пятидневной войны между Россией и Грузией в августе 2008 года инциденты бордеризации усилились. Данное явление выражается в установлении колючей проволоки вдоль административно-территориальных границ (ABL), разделяющих Грузию и Южную Осетию, а также в смещении пограничных столбов вглубь территории Грузии с целью преобразовать официально обозначенную линию прекращения огня в международную границу российскими пограничниками с ФСБ. Цель статьи состоит в исследовании того, как бордеризация повлияла на политику властных элит Грузии и Южной Осетии. Проблема бордеризации возникла в полит-социальных дебатах и позволила показать миру виктимизацию грузинского народа. Это тоже позволило, особенно в 2012-2013 годах, оценить разницу между подходами к процессу бордеризации основных политических партий в Грузии. С точки зрения Южной Осетии, бордеризация представляет собой процесс усиления народной идентичности, независимости от Грузии, а в первую очередь - доказательство статуса государства Южной Осетии, гарантом которого служило пребывание там российских военных сил, а также растущее значение военной элиты. Методология работы заключается на подходе кейс-стади, а также в критическом анализе литературы, документов, содержания интернет страниц, а кроме этого в изучении архивных материалов. В работе также использованы результаты полученные во время исследовательских поездок в 2018 и 2019 годах в Абхазию и в лагерь для вынужденно переселённых лиц в Шавшвэби, расположенный подле грузинско-южноосетинской границы.

Ключевые слова: Южная Осетия, непризнанное государство, бордеризация, политические элиты, Грузия, Россия 


\section{Wprowadzenie}

Z skalacja konfliktu pomiędzy Gruzją, Federacją Rosyjską i wspieraną Drzez nią Osetią Południową wydawała się najmniej prawdopodobną spośród pozostałych jednostek o statusie państw nieuznawanych na obszarze poradzieckim ${ }^{1}$. W nocy z 7 na 8 sierpnia 2008 roku ostrzał artyleryjski, prowadzony na linii Cchinwali (osetyjskiej stolicy) i gruzińskiego Gori, rozpoczął tzw. wojnę pięciodniową, inaczej sierpniową. W wyniku konfliktu Gruzja utraciła dostęp do 20\% swego terytorium, Rosja uznała niepodległość Abchazji oraz Osetii Południowej, w której rozpoczął się proces stopniowego wyludniania oraz izolacji od świata zewnętrznego (Cheterian, 2009; АЛАНИЯинформ, 2018).

Wzdłuż strefy, określanej jako Administracyjna Linia Graniczna (ABL), pojawiły się pierwsze przypadki borderyzacji - zjawiska polegającego na instalowaniu kolczastych murów granicznych pomiędzy Gruzją a Osetią Południową oraz na jednostronnym przemieszczaniu słupków granicznych i samowolnym wyznaczaniu przebiegu granicy przez rosyjskich strażników granicznych (Kakachia i in., 2017, s. 5). Miejsca dotknięte borderyzacją, takie jak położona w bezpośrednim sąsiedztwie Osetii Południowej wioska Churwaleti, stały się punktem wizyt zarówno gruzińskich polityków, jak i zagranicznych delegacji państwowych reprezentowanych przez dyplomatów, prezydentów, przewodniczących organizacji międzynarodowych czy dowódców wojskowych (Toal, Merabishvili, 2019, s. 2).

Kwestia granicy rozpatrywanej w wymiarze terytorialnym, regionalnym czy państwowym stała się kategorią o istotnym znaczeniu dla dyskursu politologicznego (Fras, 2013). Stanowi ona również konstrukcję bardziej symboliczną i konceptualną aniżeli tylko materialną. Paola Zaccaria (2012) określa ją mianem broni. W kontekście bezpieczeństwa narodowego przybiera kształt granicznego punktu kontrolnego, poprzez który dokonuje się ustalenia tożsamości narodowej cudzoziemca próbującego przekroczyć granicę państwa.

1 Wieloznaczność terminologiczna oraz brak konsensusu koncepcyjnego co do znaczenia definicyjnego podmiotów o statusie państw nieuznawanych, określanych jako państwa de facto, parapaństwa, quasi-państwa, państwa samozwańcze czy nieuznawane, stanowi przedmiot badań współczesnej politologii, geografii politycznej czy nauk prawnych. W niniejszej pracy w odniesieniu do Osetii Południowej autorka posługuje się pojęciem quasi-państwa. 
W 2019 r. Osetia Południowa zamknęła punkty kontrolne z Gruzją i podjęła próby własnego zabezpieczania ABL (International Federation for Human Rights, 2019).W 2017 r. Misja Obserwacyjna UE (EUMM) podała, że wzdłuż terenów granicznych rozlokowano rosyjskie wieże strażnicze. Gruzja stała się niejako zakładnikiem nieuregulowanego konfliktu etniczno-terytorialnego, zaś region Kaukazu pozostaje bardziej w sferze utrzymującej się dynamiki niż powojennej stabilizacji (de Waal, 2017).

Pomimo zakończenia zimnej wojny i zburzenia muru berlińskiego polityka budowania murów nie straciła na aktualności. Zakres borderyzacji, który zwykle ograniczał się do przestrzeni lądowej, uległ rozszerzeniu także na terytoria wodne, odnosząc to zjawisko do ustanawiania wirtualnych murów w postaci barier prawnych, takich jak odmowy azylu migrantom przekraczającym Morze Śródziemne czy patroli wzdłuż granicy morskiej, mających zapobiegać jego przekraczaniu (Zaccaria, 2012). Motyw barier granicznych stał się kluczowym elementem gry politycznej w czasie kryzysu imigracyjnego w 2015 roku, podczas którego niektórzy europejscy politycy wznosili populistyczne hasła wzywające narody do przejmowania kontroli nad własnymi granicami. Podobna narracja towarzyszyła kampanii prezydenckiej Donalda Trumpa, w czasie której pojawiał się postulat budowy wysokiego muru granicznego pomiędzy Stanami Zjednoczonymi a Meksykiem (Toal i Merabishvili, 2019). Wykorzystywanie granic jako elementu gry politycznej wpisało się w dynamikę procesów politycznych zarówno światowych potęg, jak i mniejszych państw peryferyjnych.

Celem artykułu jest zweryfikowanie hipotezy, że zjawisko borderyzacji, mające miejsce wzdłuż linii granicznej (ABL), oddzielającej Gruzję od Osetii Południowej, wpłynęło na politykę gruzińskich, a w przypadku quasi-państwa także i wojskowych elit władzy. Motyw granicy wszedł do debaty polityczno-społecznej w Gruzji w 2012 i 2013 roku, ujawniając dwie główne linie podziału w sposobie postrzegania incydentów związanych z jej naruszaniem. W dyskursie na temat Osetii Południowej (i Abchazji) doszło do zmiany pojęciowej z „separatyzmu” na „okupację”, której symbolem stała się aktywność związana z borderyzacją. Z perspektywy Osetii Południowej stanowi ona przejaw umacniania suwerenności oraz przeświadczenia o własnej państwowości, której gwarancją jest militarna obecność Rosji i rosnące znaczenie elit wojskowych. 
Niniejsze studium przypadku wpisuje się w program badawczy pt. „Kaukaz: przywództwo i elity polityczne", który jest realizowany pod kierunkiem Profesora Tadeusza Bodio w Katedrze Studiów Wschodnich Wydziału Nauk Politycznych i Studiów Międzynarodowych Uniwersytetu Warszawskiego. W weryfikacji przyjętych założeń posłużyła analiza krytyczna literatury, dokumentów, ustaw oraz przegląd archiwalnych materiałów, zawartych w zasobach elektronicznych organów administracji państwowej Gruzji, Rosji oraz EUMM.W analizie źródeł internetowych wykorzystano podejście strukturalne, zaś w ujęciu komparatystycznym przedstawiono główne linie narracji sił politycznych wobec zjawiska borderyzacji. W pracy posłużono się również wynikami uzyskanymi podczas wyjazdów badawczych w 2018 i 2019 roku do Abchazji oraz obozu dla osób wewnętrznie przesiedlonych w Szawszwebi, położonego przy granicy gruzińsko-osetyjskiej.

\section{Geneza sporu o granicę gruzińsko-osetyjską}

Etnogeneza Osetyjczyków wskazuje, że wywodzą się od najstarszego na Kaukazie ludu indoeuropejskiego. Z badań historycznych wynika, iż najprawdopodobniej pochodzą od plemienia Alanów. Kontakty z Gruzją ulegały stopniowemu zacieśnianiu i doprowadziły do przyjęcia przez Osetyjczyków chrześcijaństwa w XI wieku. W kolejnych wiekach musieli oni jednak uznać wyższość gruzińskich władców. Osetyjczycy zajmowali ziemie nazywane historycznie regionem cchinwalskim, który w pierwszej połowie XIX wieku znalazł się pod panowaniem Rosji i został włączony do okręgu Gori, a następnie wydzielony jako tzw. Osetyjski Okręg Guberni Gruzińsko-Imeretyńskiej. Status administracyjny regionu Cchinwali ulegał wielokrotnie zmianie (Джоджуа, 2007, s. 91-108).

W XX wieku bolszewicy wystosowali do władz centralnych w Moskwie memorandum, w którym domagali się wcielenia Osetii Południowej w granice państwa rosyjskiego (Janicki, 2012, s. 222-223).W 1921 roku doszło do zdefiniowania podstaw politycznego funkcjonowania jednostki. Stworzono 15-punktową konstytucję oraz zarys jej granic. Przeszkodą w realizacji przyjętych postulatów okazały się niewielkie rozmiary Osetii Południowej, które uniemożliwiłyby jej funkcjonowanie. Jednak dążenia separatystyczne ludności osetyjskiej doprowadziły do uzyskania przez republikę statusu 
obwodu autonomicznego. 20 kwietnia 1922 roku stała się ona formalnie jednostką autonomiczną - Obwodem Autonomicznym Południowej Osetii (OAPO) (Coene, 2010, s. 151) w składzie Gruzińskiej SRR. W odpowiedzi na przejawy tłumienia przez władze w Tbilisi osetyjskiej odrębności mieszkańcy jednostki inicjowali antygruzińskie manifestacje. W konsekwencji w 1989 roku Rada Obwodu ogłosiła się republiką autonomiczną, co wywołało stanowczy sprzeciw gruzińskich władz i stało się pretekstem do eskalacji starć. Ich apogeum stanowiła decyzja Tbilisi o likwidacji Obwodu. Doprowadziło to do dwuletniej blokady Osetii Południowej i zmiany jej nazwy na pierwotną - region cchinwalski (Czachor, 2014, s. 204-209).

W wyniku walk pomiędzy oddziałami osetyjskimi i gruzińskimi w 1991 roku doszło do przyjęcia przez Radę Deputowanych Aktu ogłoszenia niezależności Republiki Południowa Osetia (Декларация..., 2005; Bieleń, 2010, s. 136) ${ }^{2}$. W celu uniknięcia zagrożenia związanego z przekształceniem się napięć w regularny konflikt zbrojny prezydent Rosji Borys Jelcyn oraz nowy gruziński przywódca Eduard Szewardnadze zawarli 25 czerwca 1992 roku w Soczi tzw. Porozumienie Dagomyskie o zawieszeniu broni (Romańczuk, 2018, s. 48).

Zrujnowaną zniszczeniami wojennymi gospodarkę Osetii Południowej zasilały środki finansowe z Rosji oraz Osetii Północnej, gdzie trafiało osetyjskie drewno oraz woda mineralna. Największe zyski czerpano jednak z nielegalnych przygranicznych procederów przestępczych, którym sprzyjał brak kontroli na granicy z Gruzją. Swoboda jej przekraczania była jednym z elementów odróżniających Osetię Południową od Abchazji, której granica z państwem macierzystym od wojny (1992-1993) ma charakter zamknięty (Górecki, 2003, s. 25-26; Piskorski, 2012, s. 221).

Pozytywne relacje, jakie łączyły pierwszego prezydenta Osetii Południowej Ludwiga Czibirowa oraz prezydenta Gruzji Eduarda Szewardnadze przerwał wybór na najwyższy urząd w quasi-państwie Eduarda Kokojty w 2001 roku. Nastąpił wówczas zwrot w kierunku Rosji, któremu towarzyszył proces wydawania rosyjskich paszportów, a tym samym nadawania Osetyjczykom

2 Stanisław Bieleń wskazuje, że pojawienie się nowych jednostek państwowych po rozpadzie ZSRR było rezultatem uwarunkowań politycznych i nie miało oparcia w prawie międzynarodowym ani konstytucyjnym. Powoływanie się na samostanowienie stanowiło raczej element politycznej retoryki. 
praw emerytalnych. W okresie od 1992 do 2004 roku Osetia Południowa pozostawała jeszcze częścią gruzińskiej gospodarki, a sytuacja nieuregulowanego statusu przypominała raczej spór polityczny niż wyniszczający konflikt. Mieszkający po przeciwnych stronach linii demarkacyjnej (między regionem Gori a Osetią Południową) Gruzini i Osetyjczycy handlowali na targowisku Ergneti, będącym głównym źródłem osetyjskich dochodów, prawie w całości nieopodatkowanych i niekontrolowanych (de Waal, 2020, s. 191-192). Obrót towarów był możliwy dzięki systemowi łapówek i tzw. „kriszy”, którym określano wpływowych urzędników (patronów) z i spoza republiki. W 2004 roku w myśl zainicjowanym przez nowo wybranego prezydenta Michaiła Saakaszwilego działaniom przeciw przemytowi władze gruzińskie zadecydowały o zamknięciu targowiska (Kupatadze, 2005, s. 68-70).

Celem polityki wewnętrznej nowego przywódcy Gruzji stało się przywrócenie integralności terytorialnej z Abchazją i Osetią Południową nawet za cenę interwencji militarnych. Jednak w przeciwieństwie do sukcesu w obaleniu reżimu Asłana Abaszydze w Adżarii w 2004 roku, działania gruzińskich władz wobec Osetii Południowej w sierpniu 2008 roku zakończyły się niepowodzeniem (Czachor, 2014, s. 217-221). W rezultacie decyzji Kremla o wysłaniu do Abchazji kilkuset żołnierzy pod pretekstem naprawy linii kolejowych, a także incydentów wzdłuż granicy z Osetią Południową czy naruszania gruzińskiej przestrzeni powietrznej przez rosyjskie samoloty, Tbilisi podjęło decyzję o odwołaniu z Moskwy rodzimego ambasadora (Małachowska, 2017, s. 136).

\section{Początek zjawiska borderyzacji}

Etymologia słowa „granica” ma korzenie prasłowiańskie. W swym podstawowym znaczeniu (terytorialnym) odwołuje się ono do posiadania oraz podziału ziemi, a zatem do własności wytyczonej za pomocą specjalnych znaków, takich jak słupki czy pasy ziemi. Owo staropolskie słowo zostało później zaadoptowane do innych języków słowiańskich, a także germańskich (Fras, 2013, s. 69).

Już od czasów Cesarstwa Rzymskiego zjawisko borderyzacji odnoszone do ziem, grup etnicznych czy kultur stało się supra-narodową strategią myśli zachodniej, którą chętnie przyjmowały inne ówczesne mocarstwa (Zaccaria, 
2011). Z tego względu granice terytorialne od zawsze były związane z granicami o charakterze kulturowym czy etnicznym. Podobnie jak terytoria przygraniczne wpisują się one w koncepcję geopolityczną, która kładzie nacisk na związek pomiędzy terytorium a polityką. Wywodzące się od łacińskiego słowa „fines” - „finis terrae” oznacza granicę, której nie wolno przekraczać. Pełni ona bowiem funkcję utrzymania i obrony politycznej wizji podziału ziem ustalonej wedle tożsamości narodowo-etnicznej, językowej i kulturowej (Zaccaria, 2011, s. 114). Literatura podejmująca kwestię murów granicznych wskazuje, że na proces ich tworzenia wpływa tożsamość narodowa oraz kwestie bezpieczeństwa. Bezpieczeństwo granic stało się przestrzennym określeniem narodowości i niejako „terytorializuje” tożsamość narodową, w tym przypadku gruzińską i osetyjską. Obecność Rosji dodatkowo utrwaliła znaczenie sztucznie instalowanych granic, które przekształcają kontury terytorialne państwa gruzińskiego (Merabishvili, 2020, s. 1, 11).

Nazwa „borderyzacja” (ang. border - granica) to neologizm utworzony na określenie działań polegających na konstruowaniu kolczastych barier na terytorium oddzielającym Gruzję i Osetię Południową w celu przekształcenia formalnie wyznaczonej linii zawieszenia broni w granicę międzynarodową przez rosyjskich strażników granicznych. Po raz pierwszy termin ten został użyty przez obserwatorów EUMM w odniesieniu do linii ABL biegnącej wzdłuż granicy państwa i quasi-państwa. Zaproponowali oni trójelementową definicję borderyzacji rozumianą jako: a) tworzenie fizycznej infrastruktury w celu zmuszenia osób przekraczających granicę do korzystania ze specjalnych „kontrolowanych przejść granicznych” ulokowanych na linii ABL; b) działania obserwacyjne i patrolowe, prowadzone przez rosyjskich pograniczników lub podmioty służb bezpieczeństwa obydwu republik, w tym zatrzymania osób naruszających ustanowione przez nich zasady; c) system przekraczania granicy wymuszający posiadanie specjalnych dokumentów oraz korzystanie wyłącznie z wyznaczonych przejść (EUMM, 2018, s. 3).

Pierwszy przypadek borderyzacji miał miejsce w sierpniu 2009 roku w wiosce Kweszi, kiedy to rosyjscy pogranicznicy próbowali wyznaczyć granicę w taki sposób, że dom jednej z gruzińskich rodzin znalazł się po stronie osetyjskiej. Wywołało to natychmiastowy protest gruzińskiego Ministerstwa Spraw Zagranicznych, które nazwało te działania „próbą przenikania w głąb terytorium państwa przez rosyjskich okupantów” (Georgia Says..., 2009). 
Zjawisko borderyzacji przebiegało w sposób falowy. W latach 2009-2011 przybierało formę działań polegających na wytyczeniu i demarkacji linii granicznej, w tym oznakowaniu granicy przez słupki i wieże obserwacyjne. Wedle danych gruzińskiego Biura Publicznego Obrońcy do 2014 roku długość ogrodzenia oraz kolczastych barier wynosiła już $50 \mathrm{~km}$. Wtedy też termin „borderyzacja” wszedł do powszechnego użytku. Jednak bliższe znaczeniu samej borderyzacji oraz sposobu mówienia o ABL z Osetią Południową było określenie „linia okupacyjna”, które zdominowało kampanię prezydencką w 2013 roku. Do momentu intensyfikacji tego zjawiska w gruzińskim dyskursie politycznym posługiwano się raczej pojęciem „okupacji” (Toal, Merabishvili, 2019, s. 6-8).

Działania związane z borderyzacją obejmowały m.in. umieszczanie czujników ruchu, kamer i zielonych znaków „granicy państwa”, a także tworzenie wież obserwacyjnych oraz szerokich linii naziemnych w postaci pasów przypominających przegrody ogniowe, które rosyjscy lub południowoosetyjscy strażnicy graniczni wykorzystywali jako ścieżki patrolowe (EUMM, 2017, s. 4-5). Według danych Państwowej Służby Bezpieczeństwa Gruzji do listopada 2017 roku wzdłuż ABL zatrzymano 1109 osób. Co najmniej 34 wioski zostały podzielone drutami zainstalowanymi przez rosyjskich pograniczników, przez co łącznie od około 800 do 1000 rodzin straciło dostęp do swych ziem uprawnych (Kakachia i in., 2017, s. 9; Amnesty International, 2019). Wedle danych EUMM (2017, s. 6) stan na 2016 rok wskazywał, że rocznie dochodziło średnio do ponad 130 zatrzymań i oskarżeń o nielegalne przekroczenie granicy wobec osób przybywających od strony gruzińskiej. Pamięć o przemocy w czasie wojny z 2008 roku, a także incydenty borderyzacji wpłynęły negatywnie na postawę osób zamieszkujących tereny wzdłuż ABL z Osetią Południową. Wykazują oni mniejszą skłonność do popierania kompromisów w kwestii rozwiązania sytuacji konfliktowej aniżeli ci żyjący bliżej granicy z Abchazją (Sichinava, 2020, s. 7).

\section{Elity polityczno-wojskowe Osetii Południowej wobec borderyzacji}

Podczas wojny sierpniowej wojska rosyjskie zajęły obszary daleko wykraczające poza terytorium Abchazji oraz Osetii Południowej. Wycofując się z powrotem na wyznaczone granice obydwu republik, pozwolili sobie na 
uznaniowe wyznaczenie miejsc kontroli granicznej. Umożliwił im to fakt, iż granica osetyjska $\mathrm{z}$ okresu funkcjonowania jednostki jako obwodu autonomicznego nie była precyzyjnie wyznaczana (Toal, Merabishvili, 2019, s. 5). Po wojnie Rosja zawierała z przywódcami quasi-państw kolejne porozumienia m.in. o uznaniu niepodległości, o ustanowieniu przedstawicielstw dyplomatycznych czy Umowy o przyjaźni, współpracy i wzajemnej pomocy (Россия..., 2008).

Polityka borderyzacji stała się następstwem podpisania bilateralnych porozumień w ramach Wspólnych wysiłków na rzecz ochrony granicy państwowej Republiki Osetii Południowej z 30 kwietnia 2009 roku. Ustanawiały one wzajemne upoważnienia w celu zabezpieczenia granic republiki. Organami odpowiedzialnymi za zarządzanie sytuacją na granicy, a także ochroną liczącej ponad $391 \mathrm{~km}$ granicy z Gruzją ustanowiono Departament Straży Granicznej FSB oraz Komitet Bezpieczeństwa Państwowego Osetii Południowej (KGB). Uwagę zwraca fakt, że porozumienie z 2009 roku nie zawierało zapisu o konstrukcji jakiejkolwiek bariery na linii granicznej pomiędzy Gruzją a Osetią Południową (Toal i Merabishvili, 2019, s. 5). Powyższe upoważnienia zostały odnowione w kolejnym Dekrecie o granicach państwa z początku 2015 r. Nastąpiło to przed podpisaniem Traktatu o sojuszu i integracji przez prezydentów Władimira Putina i Leonida Tibilowa, na podstawie którego wiele kompetencji rządowych uzależniono od procesu decyzyjnego w Moskwie (Boyle, 2016, s. 5).

Terytorium Osetii Południowej stało się silnie zmilitaryzowane. Już w 2009 r. z połączenia 135. oraz 693. pułku zmotoryzowanego na terenie quasi-państwa utworzono 4. Bazę Wojskową Gwardii (Lądowych Sił Zbrojnych FR na terytorium Republiki Osetii Południowej). Jej liczebność oszacowano na około 4 tys. rosyjskich żołnierzy. Serwis informacyjny dla rodziców osób odbywających służbę wojskową podawał, że baza w Cchinwali składa się z sześciu baraków, z których każdy może pomieścić 600 żołnierzy. Oprócz bazy głównej w niewielkiej terytorialnie republice znajduje się również poligon i baza lotnicza w wiosce Dżawa (4 гвардейская..., 2015). Wojsko dysponuje ciężkim sprzętem, jest wyposażone w transportery opancerzone i artylerię, czołgi, a także pociski Toczka-U i Smercz (OБCE, 2011).

Pierwszy przypadek borderyzacji w wiosce Kweszi w 2009 roku został poprzedzony wystąpieniem Kokojty, w którym zapowiadał zgłoszenie „roszczeń 
terytorialnych" i żądania zwrotu wąwozu Truso, znajdującego się na granicy gruzińsko-rosyjskiej w regionie Kazbegi (Georgia Says..., 2009). Strona osetyjska często powoływała się na granice z czasów funkcjonowania jako okręg autonomiczny (OAPO), które miejscami nie pokrywały się z terytorium kontrolowanym przez Gruzję. Rosja i Osetia Południowa wyznaczały je zgodnie z mapami radzieckiego sztabu generalnego z 1984 roku. Na uwage zasługuje fakt, że po ogłoszeniu radzieckiej deklaracji niepodległości przez quasi-państwo w 1990 roku Gruzja zlikwidowała OAPO i podzieliła jego terytorium pomiędzy cztery gruzińskie prowincje. Ta administracyjna reorganizacja nigdy nie znalazła jednak odzwierciedlenia w terenie, a władze w Tbilisi uznają terytorium Osetii Południowej za okupowane (Boyle, 2016, s. 6).

W 2010 roku osetyjski minister obrony Walerij Jachnowiec ogłosił ukończenie budowy kompleksu wojskowo-inżynieryjnego pod nazwą „Ściany Południowej”. Składał się na niego m.in. wał przeciwpancerny i wieże obserwacyjne, mające chronić Cchinwali przed gruzińskim atakiem z południa. Realizacją działań związanych z ochroną granic Osetii Południowej zajmowała się rosyjska straż graniczna (Санакоева, 2010). W 2012 roku osetyjskie władze utworzyły strefę przygraniczną o powierzchni $761 \mathrm{~km}^{2}$, do której mieszkańcy republiki oraz Rosji mogli wjeżdżać na podstawie specjalnych przepustek. W 2017 roku złagodzono obostrzenia i zniesiono konieczność posiadania owych zezwoleń. Wymóg posiadania dokumentu tożsamości wydanego przez quasi-państwo został jednak utrzymany (Toal i Merbishvili, 2019, s. 6). Pojawiające się podczas kampanii wyborczej Bidzina Iwaniszwilego propozycje ponownego otwarcia rynku Ergneti nie zyskały aprobaty przywództwa Osetii Południowej. Premier quasi-państwa Borys Czoczijew przestrzegał przed szkodą, jaką może przynieść wznowienie handlu transgranicznego z Gruzją (Boyle, 2016, s. 14).

W 2013 roku funkcjonariusze straży granicznej FSB oraz przedstawiciele osetyjskich władz potwierdzili, że borderyzacja będzie kontynuowana. Powoływali się przy tym na bezpośredni rozkaz wydany przez wysokich rangą przedstawicieli rosyjskich sił zbrojnych. Możliwość negocjacji w tej kwestii uzależnili od zgody Gruzji na „rozmowy w sprawie demarkacji i delimitacji granicy z Osetią Południową”. W odniesieniu do przypadku borderyzacji w wiosce Ditsi dowodzący służbą graniczną quasi-państwa gen. Siergiej 
Kolbin oznajmił, iż rosyjskie oddziały straży granicznej instalują ogrodzenia, gdyż ochrona „granicy państwowej Osetii Południowej” należy do ich kompetencji (МВД..., 2013).

W 2017 roku ministrowie obrony Rosji i Osetii Południowej podpisali porozumienie o włączeniu niektórych oddziałów osetyjskich do sił zbrojnych FR. Rosyjscy wojskowi od lat zajmują najwyższe stanowiska w siłach zbrojnych republiki. Nadzór nad działaniami w dziedzinie obronności na terytorium Abchazji i Osetii Południowej pełni gen. Aleksandr Dwornikow, stojący na czele Południowego Okręgu Wojskowego Federacji Rosyjskiej. Z kolei mianowany na szefa Sztabu Generalnego i pierwszego zastępcę osetyjskiego ministra obrony gen. Wiktor Fedorow jest przedstawicielem Rosji w obydwu quasi-państwach (Komakhia, 2017). W marcu 2017 roku kierownictwo Departamentu Straży Granicznej przekazano generałowi dywizji Anatolijowi Utkinowi, od którego prezydent Osetii Południowej Anatolij Bibilow domagał się poprawy bezpieczeństwa na granicy z Gruzją i całkowitego wyeliminowania przypadków jej naruszania (Анатолий..., 2017).

W przeciwieństwie do Abchazji, gdzie nadmierna ingerencja Rosji w kwestie bezpieczeństwa wywołuje krytykę części społeczeństwa i elit politycznych, w Osetii Południowej zunifikowanie lokalnych struktur ścigania z systemem rosyjskim cieszy się silnym poparciem i doprowadziło do przejęcia przez Moskwę większej władzy w zakresie egzekwowania prawa niż w Suchumi. W tej mierze w 2016 roku na poziomie resortów spraw wewnętrznych doszło do podpisania porozumienia o utworzeniu Wspólnego Centrum Informacyjno-Koordynacyjnego. Uwagę zwraca fakt, że to właśnie strategia Utkina przyczyniła się do zatrzymania i aresztowanie ponad 900 osób (od 2009 do 2017 roku) pod zarzutem nielegalnego przekraczania granicy (Komakhia, 2017).

Dla elit władzy w Cchinwali borderyzacja stała się przejawem umacniania tożsamości narodowej, niezależności od Gruzji, a przede wszystkim przeświadczenia o osetyjskiej państwowości, której gwarantem stała się Rosja i jej polityka uznania. Szef rosyjskiej dyplomacji Siergiej Ławrow w wywiadzie dla agencji informacyjnej RIA Nowosti w 2021 roku zasugerował, że sześciopunktowe porozumienie o zawieszeniu broni z sierpnia 2008 roku nie zostało w rzeczywistości podpisane, a ,jedynie omówione”. Powołując się na brak 
wiążącej umowy pomiędzy stronami stwierdził, że uznanie niepodległości Osetii Południowej (i Abchazji) jest wynikiem braku jakiegokolwiek porozumienia dotyczącego przyszłości republik (Лавров..., 2021). Elita wojskowa reprezentowana przez wysokich rangą dowódców rosyjskich sił zbrojnych w Osetii Południowej wywiera decydujący wpływ na politykę zarządzania granicami, a tym samym sposób funkcjonowania quasi-państwa.

\section{Borderyzacja w polityce gruzińskich elit władzy}

Borderyzacja stanowi wyzwanie dla polityki wewnętrznej Gruzji, gdyż jest postrzegana jako forma terytorialnej aneksji państwa.W 2008 roku parlament przyjął ustawę Prawo Gruzji o terytoriach okupowanych w celu ustanowienia „specjalnego reżimu prawnego" wobec statusu Osetii Południowej i Abchazji, które określono jako terytoria okupowane (Law..., 2008).

Wygrana koalicji Gruzińskie Marzenie (GM) w wyborach parlamentarnych w 2012 roku nieco osłabiła postulowane przez Zjednoczony Ruch Narodowy (ZRN) przywracanie kontroli nad republikami odłączonymi w latach 90. XX wieku. GM od początku opowiadało się za normalizacją relacji z Rosją, co wyraźnie odróżniało partię od dotychczasowej retoryki ZRN wobec władz w Moskwie (Kakachia, Minesashvili, Kakhishvili, 2018, s. 818). Dlatego w 2012 roku powołano funkcję Specjalnego przedstawiciela rządu Gruzji ds. kontaktów z Rosją (PM Appoints..., 2012). Borderyzacja stała się natomiast jednym z elementów dyskursu politycznego i odegrała znaczącą rolę we wcześniejszym kryzysie związanym z protestami opozycji domagającej się rezygnacji prezydenta Saakaszwilego w 2009 roku (Toal i Merabishvili, 2019, s. 8).

Tematyka związana z kwestią granic pojawiała się w wystąpieniach towarzyszących kampanii prezydenckiej w 2013 roku. Wywołało ją zainstalowanie w wiosce Ditsi kolczastego ogrodzenia na obszarze sięgającym $300 \mathrm{~m}$ wgłąb terytorium Gruzji. Jeden z prominentnych polityków w administracji Saakaszwilego, lider ZRN Giwi Targamadze, przypisał to wydarzenie ,jednostronnym ustępstwom" rządu wobec Rosji (Installation..., 2013). Prezydent, uczestnicząc w Zgromadzeniu Ogólnym ONZ w Nowym Jorku, w przemówieniu dla gruzińskiej telewizji zarzucał rządowi prowadzenie polityki ustępstw, którą Kreml obiera jako wyraz słabości. Mówił to w kontekście 
wizyty głównego prokuratora Gruzji Arczila Kbilaszwilego w Moskwie, wypominając Iwaniszwilemu, że ten nie otrzymał zaproszenia od żadnego z zachodnich państw. Natomiast kandydujący z ramienia Ruchu Chrześcijańsko-Demokratycznego Giorgi Targamadze w kampanii wyborczej odniósł się do borderyzacji pojmowanej jako „pełzająca aneksja”, której nie powstrzyma złagodzenie retoryki rządu wobec Rosji (Saakashvili..., 2013). Toal i Merabiszwili (2017) policzyli, że w okresie poprzedzającym wybory (17 września - 27 października) w 2013 roku liczba publikacji dotyczących borderyzacji w dziale („Druty kolczaste”), sympatyzującego z ZRN portalu Tabula, wzrosła do 53, przy czym od maja do września ukazały się zaledwie cztery artykuły o tej tematyce. Zjawisko borderyzacji stało się istotnym aspektem, wokół którego rozgrywała się walka wyborcza.

Natomiast wśród wysokich rangą przedstawicieli administracji Premiera Iwaniszwilego, lidera GM, incydent w Ditsi uznano za przejaw umacniania przez Rosję pozycji zajętych i okupowanych wcześniej w wojnie z 2008 roku. $\mathrm{Z}$ tego względu większość $\mathrm{z}$ nich nie godziła się na określenie go mianem „pełzającej okupacji”. Minister ds. reintegracji Paata Zakareiszwili postrzegał je jako próbę dla gruzińskiej państwowości i pragmatycznej polityki państwa. Iwaniszwili, prezentując umiarkowane stanowisko wobec incydentu w Ditsi, wskazywał na obowiązek naprawiania relacji z Rosją. (Toal, Merabishvili, 2019, s. 10; Ivanishvili..., 2013). Jednak w odpowiedzi na owy przypadek borderyzacji szefowa gruzińskiej dyplomacji Maia Pandżikidze wysłała do Rosji notę protestacyjną. Wskazała na zaniepokojenie, jakie w gruzińskim rządzie wywołały nielegalne działania Rosji i dalsza militaryzacja okupowanych regionów. Ministerstwo Spraw Wewnętrznych poinformowało zagranicznych dyplomatów oraz przedstawicieli organizacji międzynarodowych w Gruzji o zainstalowaniu konstrukcji granicznych. Rosyjskie MSZ odpierało zarzuty o borderyzację przypisując je przedwyborczej atmosferze panującej w Gruzji (Interior..., 2013). Na kilka tygodni przed wyborami prezydenckimi w 2013 roku Iwaniszwili próbował tłumaczyć przypadki borderyzacji, łącząc je ze środkami przedsięwziętymi przez Rosję w celu zabezpieczenia Zimowych Igrzysk Olimpijskich w Soczi w 2014 roku (PM Sees..., 2013). Stanowisko to poparł również Zurab Abaszidze, który pełnił wówczas funkcję specjalnego przedstawiciela rządu ds. kontaktów z Rosją (PMıs Envoy..., 2013). Na prorosyjską postawę Iwaniszwilego miały wpływ 
powiązania biznesowe, jakie nawiązał w czasie wieloletniej kariery zawodowej w Moskwie. Stąd jego pojawienie się na gruzińskiej scenie politycznej wywołało dyskusję, w której nie wahano się przedstawiać go nawet jako elementu „kremlowskiego projektu” (Gente, 2013, s. 1).

Kończący swą kadencję prezydent Saakaszwili posługiwał się narracją mówiącą o niebezpiecznej aneksji gruzińskich terytoriów, zaś rządy GM obwiniał o utratę kontroli nad znacznymi obszarami państwa. W dotkniętej borderyzacją miejscowości Dwani mówił o okupancie „pełzającym coraz bardziej naprzód” i zagrażającym suwerenności oraz przyszłości państwa. Wskazywał na niebezpieczeństwo przecięcia głównej autostrady z zachodu na wschód Gruzji, w tym ropociągu Baku-Tbilisi-Ceyhan (BTC) (Toal i Merabishvili, 2019, s. 11). Z kolei premier Iwaniszwili podczas przemówienia w 2013 roku do nowych rekrutów wojskowych w Gori ocenił działania Rosji w 2008 roku jako agresję na Gruzję, lecz, powołując się na raport UE, wskazywał, że „strona gruzińska ponosi część winy”. Z jednej strony podkreślał zapoczątkowanie bezpośredniego dialogu $\mathrm{z}$ Rosją, z drugiej zaś uznał instalacje graniczne za nieadekwatną postawę Rosji wobec starań Tbilisi (PM Ivanishvili's..., 2013). Wraz z przewodniczącym parlamentu Dawitem Usupaszwili odrzucił zaproponowany przez Saakaszwilego na kilkanaście dni przed wyborami udział w Radzie Bezpieczeństwa Narodowego w celu omówienia borderyzacji, w tym stanowiska Tbilisi w sprawie igrzysk w Soczi (PM, Parliament..., 2013).

Saakaszwili liczył na wsparcie z zagranicy. Postrzegał zdecydowaną prozachodnią politykę zagraniczną jako sposób przeciwstawienia się rosyjskim próbom dalszej aneksji. Z tego względu Ó Beacháin i Coene (2014, s. 923) stwierdzili, że elita polityczna za rządów ZRN odwoływała się do „europejskiej tożsamości Gruzji” w celu zdobycia wewnętrznej legitymacji oraz „zachodniego patronatu”. Z kolei Gruzińskie Marzenie dokonało rozróżnienia spraw związanych $\mathrm{z}$ kwestią integralności terytorialnej, $\mathrm{w}$ tym relacji z Rosją, od polityki wobec UE. Natomiast pełniący urząd premiera Irakli Garibaszwili zapewniał w 2014 roku, że „Rosja nie jest zainteresowana aneksją" obydwu republik. (PM: 'Russia..., 2014). Polityka obozu GM była zatem o wiele bardziej zachowawcza niż ta, którą forsowały siły opozycyjne.

Wybrany w 2013 roku z ramienia Gruzińskiego Marzenia na prezydenta Gruzji Giorgi Margwelaszwili prezentował bardziej zdecydowane stanowisko 
w kwestii granic państwa. Zwracał uwagę NATO oraz UE na kwestię borderyzacji podkreślając, że bezpieczeństwo Gruzji jest związane z integracją z owymi strukturami (Toal i Margvelashvili, 2019, s. 14). Podzielał również określanie samego zjawiska mianem „pełzającej okupacji”. Minister ds. Pojednania i Równości Obywatelskiej Ketewan Cichelaszwili nazwała je „otwartym i dynamicznym procesem okupacji” (Georgia's..., 2017). Margwelaszwili wskazywał ponadto na szkodliwy wymiar borderyzacji jako zjawiska skierowanego przeciwko ludziom oraz wzajemnym kontaktom poza kolczastym ogrodzeniem. W jego ocenie instalowanie sztucznych konstrukcji nie stanowiło żadnego strategicznego celu wojskowego. Borderyzację uważał za symboliczną część większego procesu, mającego na celu utrudniać postęp deeskalacji konfliktu (President..., 2014).

W 2018 roku gruziński rząd przyjął przygotowaną przez Cichelaszwili inicjatywę ukierunkowaną na rozwiązanie sytuacji konfliktowej. Celem projektu pokojowego „Step to a Better Future” było m.in. ułatwienie wymiany handlowej czy kontaktów międzyludzkich z quasi-państwami. Mieszkańcom Abchazji oraz Osetii Południowej zaoferowano możliwość kształcenia w placówkach edukacyjnych oraz korzystanie z bezpłatnej opieki medycznej na terytorium Gruzji. Inicjatywa została jednak odrzucona przez władze quasi-państw (International..., 2018). W tym samym roku Jens Stoltenberg, sekretarz generalny NATO, zapewniał w Brukseli, że wstąpienie Gruzji do struktur Paktu Północnoatlantyckiego jest uwarunkowane jedynie wypełnieniem standardów wytyczonych przez organizację, natomiast kwestia nieuregulowanej sytuacji z Abchazją i Osetią Południową nie stanowi już przeszkody (NATO..., 2018). W 2021 roku rząd w Tbilisi powołał komisję w celu wdrożenia przyjętej w 2019 r. Gruzińskiej Strategii Państwowej na rzecz Deokupacji i Pokojowego Rozwiązywania Konfliktów. Odnosząc się do owej strategii polityki zagranicznej, szef dyplomacji David Zalkaliani z GM wskazywał na konieczność wypracowania wizji odzyskania utraconych ziem, unifikacji państwa, a tym samym podejmowania wszelkich starań, aby w Gruzji nie było już linii podziałów granicznych. (Our goal and ambition, 2021).

Gruziński dyskurs polityczny w kwestii borderyzacji charakteryzował się swoistym dualizmem. Wyznaczał go odmienny sposób postrzegania i wykorzystywania jej przez główne siły polityczne w państwie. Podczas gdy 
reprezentacja „post-saakaszwilowskiego" ZRN akcentowała jedynie destrukcyjny wpływ borderyzacji na politykę i przyszłość Gruzji, obóz rządzący skupiony wokół Gruzińskiego Marzenia prezentował nieco ambiwalentną postawę wobec konkretnych przypadków borderyzacji i podejmował próby normalizacji stosunków z Rosją. W kolejnych latach wysiłki te koncentrowały się na opracowywaniu i zatwierdzaniu przez państwo bardziej zdecydowanych strategii oraz inicjatyw pokojowych.

\section{Wnioski}

Zjawisko borderyzacji, które stało się jednym z następstw polityki uznania przez Rosję niepodległości Osetii Południowej (i Abchazji), przeniosło sytuację konfliktową na Kaukazie w wymiar sporu toczonego między strukturami państwowymi i quasi-państwowymi o granice i kontrolę terytorialną. Proces kształtowania polityki i władzy, który cechuje pionowa struktura relacji hierarchicznych wynika $\mathrm{z}$ uwarunkowań kulturowo-etnicznych. Jest to jeden $z$ elementów napędzających proces borderyzacji z perspektywy rosyjskiej oraz południowoosetyjskiej. Konflikt wokół mało znanej jednostki quasi-państwowej skupił uwagę świata ze względu na udział w nim silnego państwa sąsiadującego.

Terytoria graniczne stały się nie tyle peryferiami, co raczej epicentrami konfliktów i rywalizacji o suwerenność lub jej ochronę. Podobnie jak w przypadku uznania niepodległości obydwu jednostek przez Rosję, tak i w kwestii borderyzacji kontrolowanie i zabezpieczanie osetyjskiej granicy umożliwiło Moskwie pełną kontrolę nad procesami politycznymi i wojskowymi zachodzącymi w quasi-państwie. Toteż dzieje kształtowania się tożsamości narodowej Osetyjczyków wyznaczały okresy zmian statusu zajmowanych przez nich ziem.

Zjawisko borderyzacji wykreowało sytuację, w której swą aktywność zaznaczyło wielu aktorów: gruzińskie elity polityczne, osetyjskie siły polityczno-wojskowe, a także Rosja i społeczność międzynarodowa, w szczególności UE. Z jednej strony, incydenty związane $z$ naruszaniem granic państwa pozwoliły Gruzji na ukazanie wiktymizacji własnego narodu poprzez prezentowanie światu fizycznych efektów borderyzacji. Z drugiej zaś stały się elementem żywego dyskursu, który elity władzy w odmienny, 
lecz korzystany dla własnego obozu partyjnego sposób wykorzystywały w walce politycznej. Narracja towarzysząca polityce borderyzacji w Osetii Południowej opierała się na trudnych do zweryfikowania granicach OAPO oraz pozostałościach radzieckiej kartografii wojskowej. Aktywność przygraniczna stała się wyrazem dalszego umacniania odrębności quasi-państwa od państwa macierzystego, a tym samym pogłębiania militarnej zależności od patrona oraz wzrastającej roli elit wojskowych.

\section{MGR AGNIESZKA TOMCZYK}

Wydział Nauk Politycznych i Studiów Międzynarodowych

Uniwersytet Warszawski

ul. Krakowskie Przedmieście 3, 00-047 Warszawa

a.tomczyk4@uw.edu.pl

\section{Bibliografia}

АЛАНИЯинформ. (2018, 13 lutego). Какова рождаемость в Южной Осетии? Роbrane z: http://osinform.org/64904-kakova-rozhdaemost-v-yuzhnoy-osetii.html.

Amnesty International. (2019, 3 lipca). Georgia/Russia: Post-conflict boundary splits communities, leaving thousands in limbo. Pobrane z: https://www.amnesty.org/en/ latest/news/2019/07/georgiarussia-post-conflict-boundary-splits-communities-leaving-thousands-in-limbo/.

Анатолий Бибилов: «Защита государственной гранищы - ответственная и сложная задача». (2017, 29 maja). Pobrane z: https://south-ossetia.info/anatolij-bibilov-zashhita-gosudarstvennoj-granicy-otvetstvennaya-i-slozhnaya-zadacha/.

Bieleń, S. (2010). Polityka w stosunkach międzynarodowych. Warszawa: Oficyna Wydawnicza ASPRA-JR.

Bodio, T., Marszałek-Kawa, J. (red.). (2018). Polityka, prawo, kultura i bezpieczeństwo na obszarze poradzieckim. Toruń: Wydawnictwo Adam Marszałek.

Bodio, T., Marszałek-Kawa, J. (red.). (2020).Z badań nad historiq i współczesnościa Rosji, Azji Centralnej i Kaukazu. Toruń: Wydawnictwo Adam Marszałek.

Boyle, E. (2016). Borderization in Georgia: Sovereignty Materialized. Eurasia Border Review, 7(1), 1-18. Pobrane z: http://src-h.slav.hokudai.ac.jp/publictn/eurasia_border_review/V0171/01-Boyle.pdf.

Cheterian, V. (2009). The August 2008 war in Georgia: from ethnic conflict to border wars. Central Asian Survey, 28(2), 155-170.

Coene, F. (2010). The Caucasus: an introduction. Abington: Routledge.

Czachor, R. (2014). Abchazja, Osetia Południowa, Górski Karabach: geneza i funkcjonowanie systemów politycznych. Wrocław: Fundacja Instytut Polsko-Rosyjski. 
de Waal, T. (2017, 28 marca). Whither the South Caucasus? Pobrane z: https://carnegieeurope.eu/2017/03/28/whither-south-caucasus-pub-68427.

de Waal, T. (2020). South Ossetia Today. W: T. de Waal, N. von Twickel (red.). Beyond Frozen Conflict. Scenarios for the Separatist Disputes of Eastern Europe (187-203). Brussels-London: Rowman \& Littlefield International.

Декларация о независимости Республики Южная Осетия. (2005, 27 czerwса). Роbrane z: http://cominf.org/node/1127814361.

Джоджуа, Т. (2007). История ихинвальского региона (Южная Осетия). W: К. Мацузато (red.). Историограбический диалог вокруг непризнанных государств: Приднестровъе, Нагорный Карабах, Армения, Южная Осетия и Грузия. Sарроro: Hokkaido University.

EUMM. (2017). The EUMM Monitor. (4). Pobrane z: https://eumm.eu/data/file/5774/ The_EUMM_Monitor_Issue April ENG.M1UBLiudw.PDF.

EUMM. (2018). The EUMM Monitor. (7). Pobrane z: https://eumm.eu/data/file/6486/ The_EUMM_Monitor_issue_7_ENG.pdf.

Fras, J. (2013). Istnieją tylko pogranicza, nie granice. Pogranicze. Polish Borderlands Studies, 1(1), 69-70.

Gente, R. (2013). Bidzina Ivanishvili, a man who plays according to Russian rules? Caucasus Survey, 1(1), 117-126.

Georgia's Reconciliation Minister: “It's not creeping occupation, it's a dynamic occupation”. (2017, 11 lipca). Pobrane z: https://www.agenda.ge/en/news/2017/1466.

Georgia Says Russia Tries to Shift S.Ossetia Border. (2009, 3 sierpnia). Pobrane z: https:// old.civil.ge/eng/article.php?id=21319.

Górecki, W. (2003). Osetia Południowa. W: K. Strachota (red.). Konflikty zbrojne na obszarze postradzieckim. Stan obecny, perspektywy uregulowania, konsekwencje. Prace Ośrodka Studiów Wschodnich (23-26). Warszawa: Ośrodek Studiów Wschodnich.

Installation of Fences at S.Ossetia Administrative Border. (2013, 27 maja). Pobrane z: http://civil.ge/eng/article.php?id=26117.

Interior Ministry Briefs Diplomats on 'Borderisation'. (2013, 4 czerwca). Pobrane z: https:// old.civil.ge/eng/article.php?id=26144.

International Federation for Human Rights. (2019, 22 listopada). Georgia: Checkpoint Closures Have Led to a Critical Humanitarian Situation in South Ossetia. Pobrane z: https://www.fidh.org/en/region/europe-central-asia/georgia/ georgia-checkpoint-closures-have-led-to-a-critical-humanitarian.

International response to the new peace initiative "A Step to a Better Future" adopted by the GoG on April 4, 2018. (2018, 4 kwietnia). Pobrane z: https://smr.gov.ge/uploads/ prev/internatio_fe0b65f2.pdf.

Ivanishvili Comments S.Ossetia Administrative Border. (2013, 31 maja). Pobrane z: https:// old.civil.ge/eng/article.php?id=26132.

Janicki, K. (2012). Osetia Południowa. Trzy ludobójstwa czy ratowanie ojczyzny? (do 1992). W: K. Janicki (red.).Źródła nienawiści. Konflikty etniczne w krajach postkomunistycznych (205-255). Kraków-Warszawa: Instytut Wydawniczy ERICA (Wydanie elektroniczne).

Kakachia, K. i in. (red.). (2017). Mitigating Russia's borderization of Georgia: A strategy to contain and engage. Tbilisi: Georgian Institute of Politics. 
Kakachia, K., Minesashvili, S., Kakhishvili, L. (2018). Change and Continuity in the Foreign Policies of Small States: Elite Perceptions and Georgia’s Foreign Policy Towards Russia. Europe-Asia Studies, 70(5), 814-831.

Komakhia, M. (2017, 15 listopada). Russia's Influence over the Field of Security in Tskhinvali Region is Growing: Support for Full Integration. Pobrane z: https://www.gfsis. org/blog/view/766.

Kupatadze, A. (2005). The impact of the Rose Revolution on smuggling through Abkhazia and South Ossetia. Insight Turkey, 7(4), 67-76.

Law of Georgia on occupied territories. (2008, 23 października). Pobrane z: https://matsne. gov.ge/en/document/download/19132/5/en/pdf.

Лавров об августовской войне и Соглашении из шести пунктов о прекращении огня. (2021, 29 kwietnia). Pobrane z: https://civil.ge/archives/416601.

Małachowska, K. (2017). Przyczyny wojny pięciodniowej i sytuacja geopolityczna Gruzji po konflikcie z Federacją Rosyjską. Gdańskie Studia Międzynarodowe, 15(1-2), 132-147.

Merabishvili, G. (2020). The Politics of Border Walls in Hungary, Georgia and Israel. Arlington: VTechWorks.

МВД ознакомило дипломатов с деталями т.н. «обустройства границьљ». (2013, 4 czerwca). Pobrane z: https://civil.ge/ru/archives/180660.

NATO Sec-Gen: Georgia won't have to choose between its territorial integrity and NATO. (2018, 2 paźziernika). Pobrane z: https://agenda.ge/en/news/2018/2047.

ОБСЕ. (2011, 28 styсzпia). Заявление по поводу сообщений о развертьвании Россией ракет SS-21 в регионе Южная Осетия. Pobrane z: https://www.osce.org/files/f/ documents/9/7/76800.pdf.

Ó Beacháin, D., Coene, F. (2014). Go West: Georgia's European Identity and Its Role in Domestic Politics and Foreign Policy Objectives. Nationalities Papers: The Journal of Nationalism and Ethnicity, 42(6), 923-941.

Our goal and ambition is to create a unified national process and to develop a strategic vision on de-occupation and peaceful conflict resolution. (2021,21 czerwca). Pobrane z: https://mfa.gov.ge/News/chveni-mizani-da-ambiciaa,-shevqmnat-saerto-erovnu. aspx?CatID=5\&lang=en-US.

Piskorski, M. (2012). Elity Republiki Południowej Osetii na tle kryzysu wyborczego w latach 2011-2012. W: T. Bodio (red.). Kaukaz: mechanizmy legitymizacji i funkcjonowania elit politycznych (219-247). T. VII. Warszawa: Oficyna Wydawnicza Aspra.

PM Appoints Special Envoy for Relations with Russia. (2012, 1 listopada). Pobrane z: https://old.civil.ge/eng/article.php?id=25407.

PM Ivanishvilis Speech on Fifth Anniversary of August War. (2013, 8 sierpnia). Pobrane z: https://old.civil.ge/eng/article.php?id=26345.

PM, Parliament Speaker Snub NSC as Saakashvilis PR Stunt. (2013, 9 października). Pobrane z: https://old.civil.ge/eng/article.php?id=26533.

PM: 'Russia Not Interested in Annexing' Abkhazia, S.Ossetia. (2014, 11 czerwca). Pobrane z: https://old.civil.ge/eng/article.php?id=27342.

PM Sees Link Between 'Borderisation' and Sochi Olympics. (2013, 25 września). Pobrane z: https://civil.ge/archives/186791. 
PM’s Envoy for Russia Briefs MPs on Talks with Moscow’. (2013, 27 września). Pobrane z: https://civil.ge/archives/186796.

President Condemns 'Borderization'. (2014, 26 lutego). Pobrane z: http://www.civil.ge/ eng/article.php?id=26981.

Россия подписала договорь о дружбе и сотрудничестве с Южной Осетией и Абхазией. (2008, 17 września). Pobrane z: https://www.dw.com/ru/pocсия-подписала-договоры-о-дружбе-и-сотрудничестве-с-южной-осетией-и-абхазией/а-3650818.

Romańczuk, M. (2018). The Russian Federation's involvement in peace missions after the dissolution of the USSR. Acta Politica Polonica, 2(44), 41-52.

Saakashvili Comments on 'Borderisation'. (2013, 24 września). Pobrane z: https://old.civil. ge/eng/article.php?id=26484.

Санакоева, 3. (2010, 28 października). В Южной Осетии соорудили „Южный вал”. Pobrane z: https://www.ekhokavkaza.com/a/2203182.html.

Sichinava, D. (2020). How Far is Too Far? Public Opinion on Conflict Resolution in Georgia. W: L. Badalyan i in. (red.). Public Opinion In Georgia: New Caucasus Barometer Results. Caucasus Analytical Digest, 116, 3-8. Pobrane z: https://www. research-collection.ethz.ch/bitstream/handle/20.500.11850/428141/CaucasusAnalyticalDigest116.pdf? sequence $=3$ \&isAllowed $=y$.

Toal, G., Merabishvili, G. (2019). Borderization theatre: geopolitical entrepreneurship on the South Ossetia boundary line, 2008-2018. Caucasus Survey, 7(1), 1-24. Pobrane z: https://www.researchgate.net/publication/330605766_Borderization_theatre_geopolitical_entrepreneurship_on_the_South_Ossetia_boundary_line_2008-2018.

Zaccaria, P. (2012). Medi-terranean Borderization, or deterritorializing Mediterranean space. W: L. Cazzato (red.). Anglo-Southern Relations: From Deculturation to Transculturation, (106-127). Lecce: Salento Books (Negroamaro).

4 гвардейская военная база (в/ч 66431). (2015, 26 stycznia). Pobrane z: https://voinskayachast.net/suhoputnie-voyska/motostrelkovie/vch66431. 